\title{
The Type of Leprosy Based on the Characteristics of Lepers in West Papua Province and North Maluku Province; Comparative Studies
}

\author{
Melda Suebu ${ }^{1}{ }^{2}$, Clara Imaniar ${ }^{1}$, Tri Wahyuni ${ }^{1}$, Ratna Tanjung ${ }^{1}$, Maria Hukubun ${ }^{2}$, \\ Sophia Yansip ${ }^{1}$, Vhatim Dwi Cahya ${ }^{1}$ \\ ${ }^{1}$ Center Of Papua Health Research and Development, Papua,Jayapura 99111, Indonesia \\ 2 Publich Health Faculty of Cenderawasih University, Papua, Jayapura 99351, Indonesia
}

\section{A R T I C L E I N F O}

\section{IAKMI IPHJI use only:}

Received date : 20 April 2020

Revised date : 2 May 2020

Accepted date : 6 June 2020

\section{Keywords}

Leprosy

Characteristics

West Papua

North Maluku

\begin{abstract}
A B S T R A C T
The prevalence of leprosy cases has increased every years, the government program has been on going until now, but leprosy cases are still a national problem. The purpose of this study is to describe the type of leprosy based on the characteristics of lepers. The study used a community-based crosssectional design. The results obtained that West Papua Province and North Maluku Province have leprosy burden with the same classification type, namely Multybaciller (MB) type. Male gender has more MB type of leprosy. West Papua and North Maluku. Based on the age of MB leprosy type in West Papua, the highest age range is $15-26$ years and Paucybaciller (PB) at age $>14$ years, North Maluku is most at age 27-44 years and PB at age $>14$ years. Conclution. The type of leprosy in general is the type of multibasilarry (MB), this means that leprosy is still a major threat to a comunnities, leprosy cases are also found in male gender with MB type and many cases of leprosy occurs in patients with young adult and adult age.
\end{abstract}

(c) 2020 IAKMI Indonesian Public Health Journal. All rights reserved

\section{INTRODUCTION}

Leprosy is a infecsius desease and chronic, caused by Mycobacterum leprae (M. leprae) mainly attacks the peripheral nerves and can cause disability, and cause stigma for people with leprosy $[1,2]$. Until now leprosy has become a public health problem [3]. Leprosy has become a very complex national problem because it has an impact on social, economic and national resilience problems [4].

The prevalence of leprosy is still high in developing countries and some sufferers from economically weak groups [5]. Based on epidemiological data from the World Health Organization (WHO) report that Indonesia ranks third after India and Brazil with a 2017 prevalence of 15910 per 10,000 population and an increase in 2018 of 208,613 new cases. The prevalence rate of leprosy in Indonesia reaches

\footnotetext{
* Corresponding author.

E-mail address: msuebu@gmail.com
}

0.71 per 10,000 population, the number of new case finding is 16,826 cases ( 6.50 per 10,000 population) in 2016 [6].The number of new cases is $4.19 \%$ of which are multibacillary types, male sex at $37.53 \%$ from $62.47 \%$ and others are female sex [1].

In Indonesia, there are still several provinces with a prevalence above 1 per 10,000 population, this adoption is an indicator of leprosy. The number of leprosy increases every year, and distinguish between areas of high leprosy load and areas of low leprosy load. Regions are said to have high leprosy burden if the case finding is $>10,000$ per population or the number of new cases is more than 1000 cases. Areas with high leprosy burden include the whole of Eastern Indonesia [7].

The highest number of new leprosy cases per 10,000 population in $2015-2017$ was West Papua with 86.09 cases per 10,000 population and the second was North Maluku province with 46.14 cases per 10,000 population [7]. Leprosy cases in children nationally it was 
11.05 per 10,000 population in 2017 and the highest province in the province of West Papua was 27.28 per 10,000 population and ranked second was North Maluku province at 26.34 per 10,000 population [7].

To support government programs and realize one of the goals of the 2016-2020 leprosy standard goal is to work with other parties to identify [6]. This research purpose is an interesting source of information to be a supporting basic data for making local government policy by knowing the type of leprosy based on the characteristics of leprosy patients in the provinces of West Papua and Papua Province.

\section{METHOD}

This study was conducted in May 2017 September 2018. This type of research is an analytical survey research with cross sectional research design. The number of respondents in this study were 95 leprosy sufferers in West Papua Province and 97 sufferers in North Maluku Province. The technique used is nonprobability sampling using total sampling. Research conducted in West Papua Province includes; Manokwari, Sorong, Raja Ampat. For research conducted by North Maluku through Ternate, Halmahera.

\section{RESULTS AND DISCUSSION}

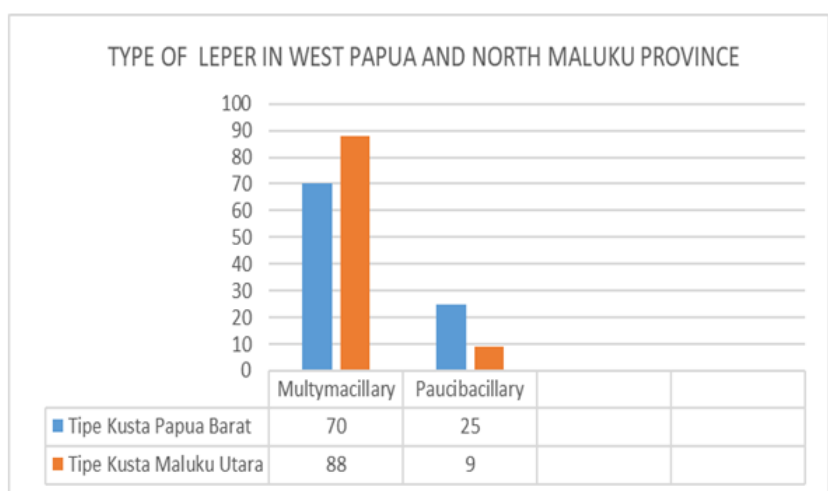

Fig 1. Type of Leper in West Papua Province and North Maluku Provinsi

Fig 1. Type of Leprosy MB is more found in lepers. This research also found the number of MB lepers more than PB type of the New Testament. Province of West Papua and North Maluku province. As much as $88(9.8 \%) \mathrm{MB}$ case in North Maluku and 70 (74\%) MB case in West Papua province. The cases of MB in North
Maluku Profinsi are higher if compared with West Papua province. The results of this study proved data according to Indonesian data center and health information that, the province with the highest case of leprosy in Indonesia during 2015-2017 was the Maluku province as much as $102.84 \%[7,8]$.

The case of the MB type of leprosy is more found in people than in PB-type leprosy. In this study, the aMB leprosy case in the province of North Maluku and West Papua province is equally high in comparing the type of $\mathrm{PB}$ leprosy in both provinces. Another research result mentions that the case of a MB leprosy was found and many more caused defects [9]. Another similar study found that the MB leprosy was much more than a PB type.

In general, the characteristics of leprosy more sufferers with a type of leper MB compared to $\mathrm{PB}$. In general, the type of leper MB is due to diagnosis and low level of knowledge. To overcome the delay of diagnosis of lepers should be conducted active surveys or early detection of the community, and conduct routine health promotion action to improve the knowledge of society [8].

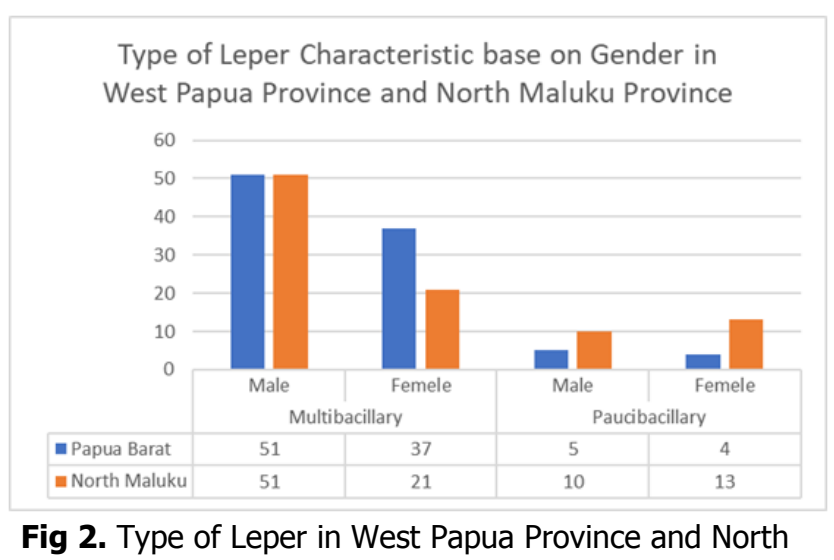
Maluku Provinsi base on Gender

North Maluku Province. The results of other similar research males have more leprosy than women [8]. Other studies have stated that gender has no effect on MB-type leprosy Events [3]. Another study similar to the study of Andy Muharry stated that the type of color Lak-male Palin has been affected by leprosy but gender is not a factor of leprosy-type triggers.(Selatan et al. 2013) The results of our study that the more MB-type of more than one of the types of males could be caused by the behavioral self-hygiene factors, where other research results proved that individual 
sanitation in the lacquers - males were worse than women [10].

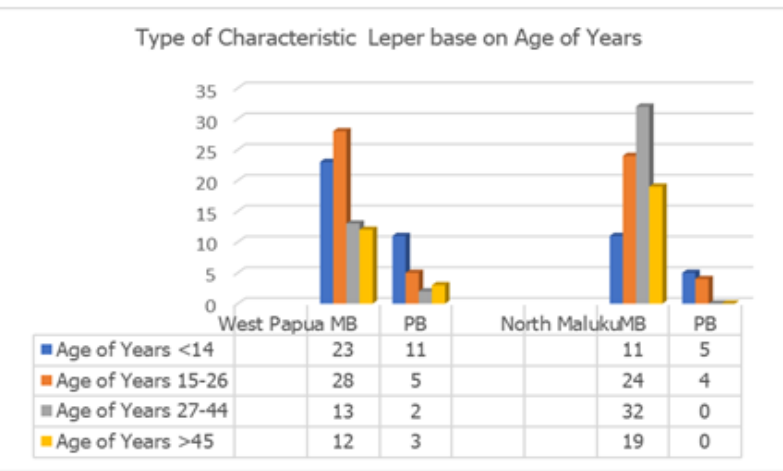

Fig 3. Type of Leper in West Papua Province and North Maluku Provins Base on Age of years

The province of North Maluku-type MB is widely found in the adult age range is $27-44$ years old. There are several similar studies where the age of 15 years and older is a much leprosy age. Other studies have claimed that many leprosy occurs at a productive age. Age where a person has a broad association that is more prone to contracting. [7]. The others results of research stating that there is no relationship between age and leprosy [3]. Although age has no connection to the incidence of leprosy but the behavior of age has an important role in the incidence of leprosy. Another factor that affects the type of leprosy is the nutritional factor. Family nutrition is influenced by economic factors as well as family income. The type of leprosy on a leprosy Seoran can be influenced by many factors, among them the knowledge factor, education level factor, economic factors

\section{CONCLUSION}

The type of leprosy in general is the type of multibasilarry (MB), this means that leprosy is still a major threat to a comunnities, leprosy cases are also found in male gender with MB type and many cases of leprosy occurs in patients with young adult and adult age.

\section{ACKNOWLEDGMENT}

$\mathrm{dr}$ antonius oktavian, head of Center of Papua Health recearch and development. Leprosy Group in Center Of Papua Recearch and Development. Hana Krismawati, M.Sc as lepra group coordinator. a team of article compilers of the papua province and north maluku province who participated as a sample in the study.

\section{REFERENCES}

[1] Gunawan, Hendra, Muljaningsih Sasmojo, Helena Eka Putri, Erda Avriyanti, Reti Hindritiani, and Oki Suwarsa. 2018. "Clinical Pilot Study: Clarithromycin Efficacy in Multibacillary Leprosy Therapy." 152-55.

[2] van 't Noordende, Anna T., Ida J. Korfage, Suchitra Lisam, Mohammed A. Arif, Anil Kumar, and Wim H. van Brakel. 2019. "The Role of Perceptions and Knowledge of Leprosy in the Elimination of Leprosy: A Baseline Study in Fatehpur District, Northern India." PLoS Neglected Tropical Diseases 13(4):e0007302.

[3] Andy Muharry, 2014. n.d. "Faktor Risiko Kejadian Kusta."

[4] Kementerian Kesehatan, 2019. "Pedoman Penanggulangan Kusta."

[5] Aprizal, Lutfan Lazuardi, and Hardyanto Soebono. 2017. "Faktor Risiko Kejadian Kusta Di Kabupaten Lamongan Risk Factors of Leprosy in District of Lamongan." Berita Kedokteran Masyarakat (BKM Journal of Community Medicine and Public Health) 33(9):427-32.

[6] WHO. 2018. "Global Leprosy Update, 2017: Reducing the Disease Burden Due to Leprosy." Weekly Epidemiological Record 35(35):445-56.

[7] Kementerian Kesehatan. "InfoDatin-Kusta2018."

[8] Cucu Herawati dan Sudrajat. Syntax Literate : Jurnal Ilmiah Indonesia - ISSN : 2541-0849 e-ISSN : 2548-1398 Vol. 3, No. 7 Juli 2018

[9] Firdaus, Fariska. 2019. "Risiko Keterlambatan Berobat Dan Reaksi Kusta Dengan Cacat Tingkat 2." Jurnal Berkala Epidemiologi 7(1):25-2.

[10] Zakiudin, Ahmad. 2016. "Perilaku Kebersihan Diri (Personal Hygiene) Santri Di Pondok Pesantren Wilayah Kabupaten Brebes." Jurnal Promosi Kesehatan Indonesia 11(2):64-83. 
IAKMI Public Health Journal Indonesia

Volume 1 No 1 June 2020

Website : http://jurnal.iakmi.id/index.php/IPHJI

e-ISSN : 2722-550X 